\title{
Mechanism of malabsorption in giardiasis: a study of bacterial flora and bile salt deconjugation in upper jejunum
}

\author{
B. N. TANDON, ${ }^{1}$ R. K. TANDON, B. K. SATPATHY, AND SHRINIWAS \\ From the All-India Institute of Medical Sciences, Ansari Nagar, New Delhi, India.
}

SUMMARY Sixty-three unselected cases of giardiasis, with no evidence of other systemic disease, were screened for evidence of steatorrhoea. No patient had any evidence of protein-energy malnutrition. Seventeen $(27 \%)$ of the cases had steatorrhoea; three $(17.8 \%)$ of the 17 patients having steatorrhoea also had D-xylose malabsorption. Vitamin $\mathbf{B}_{\mathbf{1 2}}$ absorption was normal in all. Bacterial culture and qualitative analysis of bile salt in jejunal fluid was carried out in all the 17 cases having steatorrhoea as well as 13 cases with normal absorptive parameters (eight cases of irritable bowel syndrome and five cases of giardia infection) who served as controls. Significant bacterial overgrowth was noted in eight of the 17 cases and in none of the 13 controls. All the patients showing bacterial overgrowth had free bile acids in their duodenal aspirate. Free bile acids could also be detected in jejunal aspirates of five of the seven patients having no bacterial overgrowth. Two control cases of giardia infection with normal small bowel function and sterile duodenal aspirate showed evidence of bile salt deconjugation. The significance of these findings is discussed in relation to the pathogenesis of steatorrhoea in patients with giardiasis. The possible role of giardia in bile salt deconjugation is suggested.

Giardiasis is an important cause of malabsorption both in children (Véghelyi, 1939; Cortner, 1961; Nair, 1970) and adults (Manson-Bhar, 1943; Amini, 1963; Antia et al., 1966; Tewari and Tandon, 1974). The mechanism of malabsorption in these patients has not been adequately investigated. The following pathogenic factors have been suggested: (1) a mechanical barrier to absorption (Véghelyi, 1940; Tandon et al., 1974); (2) injury to the intestinal mucosa without invasion (Yardley et al., 1964; Hoskins et al., 1967); (3) mucosal invasion by parasites (Brandborg et al., 1967); and (4) bacterial overgrowth in the upper small bowel (Yardley et al., 1964). A number of investigators have studied the injury to the intestinal mucosa in patients with Giardia lamblia infection (Zamcheck et al., 1963; Yardley et al., 1964; Tewari and Tandon, 1974) but we found no published data on bacterial flora of the

1 Address for reprint requests: Professor B. N. Tandon, Department of Gastroenterology and Human Nutrition, AllIndia Institute of Medical Sciences, Ansari Nagar, New Deihi-110016, India

Received for publication 30 September 1976 upper small gut in these patients. Bacterial overgrowth is known to be associated with deconjugation of bile salts in the stagnant loop syndrome (Gorbach and Tabaqchali, 1969). The present study was therefore carried out to investigate the bacterial content and the bile acid profile in the duodenal aspirate of patients with giardiasis and steatorrhoea.

\section{Methods}

Sixty-three patients were selected on the basis of the presence of Giardia lamblia cysts in their faecal samples. They were screened for evidence of steatorrhoea by seven day fat balance study (King and Wootton, 1964). Patients whose faecal fat excretion was more than $6 \mathrm{~g}$ in 24 hours were investigated by the following laboratory tests: haemogram, serum proteins, barium meal examination of the upper gastrointestinal tract, D-xylose absorption (Santini et al., 1961), Schilling test (Schilling, 1953), and blood immunoglobulins (Fahey and McKelvy, 1965). Eight patients with the irritable bowel syndrome and five patients with giardiasis but with normal small 
bowel absorptive function served as the controls. Bacterial culture and bile studies were undertaken in all the patients with steatorrhoea and in the controls.

Duodenal fluid was obtained after an overnight fast by using a double lumen tube positioned fluoroscopically at the ligament of Treitz. Aspirated fluid was immediately examined for Giardia lamblia.

The specimens for bacteriological examination were collected with a sterile syringe in a sterile screwcapped glass container. In addition, a known amount of fluid was immediately inoculated into Robertson's cooked meat media in proportion of 1:10 to recover fastidious anaerobic bacteria. Robertson's cooked meat media was deaeriated before inoculation, and was sealed with sterile liquid paraffin after inoculation. The specimens were transferred to the laboratory as soon as possible, where 10 -fold dilutions of the fluid were made in peptone water for aerobic culture from $10^{-1}$ to $10^{-4}$ and $0.01 \mathrm{ml}$ of each dilution was inoculated without delay (within one hour of collection) on one blood agar plate, one MacConkey's agar, and one desoxycholate citrate agar plate. Five percent sheep blood agar plates were used in the present study. The plates were incubated aerobically, at $37^{\circ} \mathrm{C}$ for 48 hours. The contents of the inoculated Robertson's cooked meat medium were also serially diluted in the same way as described above, except that the diluent fluid was deoxygenated charcoal water instead of peptone water. One hundred millilitres of the dilutions were inoculated on blood agar plates. Inoculated blood agar plates were incubated anaerobically in an anerobic jar fitted with a cold catalyst (Torbal Model-AJ-2. Torsion Balance Co. Clifton, New Jersey, USA) for 48 hours. Carbon dioxide could not be added to the anaerobic jar. Only on rare occasions were the uninoculated materials kept in the refrigerator for two to four hours before processing for aerobic culture and the inoculated Robertson's cooked medium was kept in the incubator at $37^{\circ} \mathrm{C}$ before processing. The number of colonies growing on blood agar plates inoculated with different dilutions of the fluid after 48 hours was recorded and the mean number of colonies grown aerobically and anaerobically per millitre was then calculated. The dilutions giving less than 10 colonies or more than 200 colonies were disregarded in calculating the mean number. The organisms were then identified on the basis of Gram's staining, motility, cultural characteristics, and biochemical reactions according to Cruickshank (1965), Stokes (1968), and Lennette et al. (1970).

Proteins were immediately precipitated from the duodenal aspirates by repeated alcoholic extractions and extraneous lipids were removed by partitioning with $\mathrm{n}$-heptane. These processed samples were stored at $-20^{\circ} \mathrm{C}$ until 24 to 72 hours when they were streaked on thin layer chromatographic plates. Thin layer chromatography of bile salts was done using plates coated with $250 \mu$ thick layer of Silica gel G (E. Merck) and a solvent system consisting of n-heptane 2: isopropyl ether 1:isopropyl alcohol 1:glacial acetic acid 1 (Kapadia et al., 1971).

\section{Results}

Seventeen of the 63 patients showed evidence of steatorrhoea. The clinical features of patients with and without steatorrhoea were compared. Abdominal discomfort or pain was the commonest symptom in both the groups. Recurrent loose motions, flatulence, malaise, and mucus in the stools were the other prominent symptoms. Twenty-four per cent of the patients in the group with steatorrhoea complained of passage of bulky, frothy stools but none of the patients in the other group had this symptom. Weight loss, documented or undocumented, was present in both the groups, but it was more frequent in the patients with steatorrhoea. The duration of diarrhoeal symptoms varied from two months to 12 years. More than half of the patients had had them for more than one year. None of the patients showed any clinical evidence of vitamin deficiencies. Haematological investigations in 17 patients with giardiasis and steatorrhoea revealed a mean serum protein and albumin level of $6.8 \mathrm{~g}$ and $4 \mathrm{~g} \%$ respectively. Mild hypoalbuminaemia $(3 \cdot 26-3 \cdot 75 \mathrm{~g} \%)$ was recorded in two. The ESR was raised in four patients. Differential leucocyte count showed an eosinophil count between 5 to $15 \%$ in seven and $5 \%$ or less in the rest of the cases. Mild anaemia with a haemoglobin value between 10 to $12.9 \mathrm{~g} \%$ was recorded in eight patients. Blood immunoglobulins were normal in all. Abnormal D-xylose excretion was observed in three of the $17(17.8 \%)$ cases. The Schilling test was normal in all.

Table 1 Results of bacterial culture study in jejural aspirate from patients with giardiasis and controls

\begin{tabular}{lllll}
\hline & \multicolumn{3}{l}{ Cases with: } & \\
\cline { 2 - 5 } Subjects & $\begin{array}{l}\text { Total } \\
\text { cases }\end{array}$ & $\begin{array}{l}\text { Bacterial } \\
\text { overgrowth } \\
10^{5} \text { col/ml } \\
\text { or more }\end{array}$ & $\begin{array}{l}\text { Minimal } \\
\text { growth } \\
10^{4} \text { col/ml } \\
\text { or less }\end{array}$ & $\begin{array}{l}\text { Sterile } \\
\text { culture }\end{array}$ \\
\hline $\begin{array}{l}\text { Patients with } \\
\text { giardiasis with } \\
\text { steatorrhoea }\end{array}$ & 17 & $8(48 \%)$ & 1 & 7 \\
$\begin{array}{l}\text { Controls: } \\
\text { 1. Irritable bowel } \\
\text { syndrome }\end{array}$ & 8 & 0 & 2 & 6 \\
$\begin{array}{l}\text { 2. Giardia infection } \\
\text { without } \\
\text { malabsorption }\end{array}$ & 5 & 0 & 0 & 5 \\
\hline
\end{tabular}


The incidence of bacterial overgrowth $\left(10^{5} \mathrm{orgs} / \mathrm{ml}\right.$ juice) is shown in Table 1 . Eight patients (48\%) had an abnormal overgrowth of bacteria, one patient yielded Nisseria and micrococci (as both were nonpathogenic organisms they were not considered as an abnormal overgrowth), one patient had a minimal bacterial growth $\left(10^{4} \mathrm{org} / \mathrm{ml}\right.$ juice $)$, and seven samples were sterile. Two of the eight patients with the irritable bowel syndrome had minimal growth and six had a sterile culture. All the five patients with giardiasis without malabsorption had sterile duodenal aspirate. All the three samples which had to be kept in referigeration for two to four hours were sterile: two were from patients with giardiasis and steatorrhoea and the remaining one was from a control subject. The types of organism grown and their concentration is shown in Table 2. The organisms were a mixed group of cocci and bacilli, with the gram negative group predominating.

Table 3 shows the incidence of bile salt deconjugation in patients and controls. Fourteen or $82.5 \%$ of the patients showed free bile acids in jejunal fluid. None of the eight patients with the irritable bowel syndrome showed deconjugation. Two of the five patients with giardiasis without the malabsorption syndrome showed bile salt deconjugation. The relation between bile salt deconjugation and bacterial overgrowth is shown in Table 4. Of the eight patients

Table 2 Bacteriological data of patients having bacterial overgrowth

\begin{tabular}{|c|c|c|}
\hline Slide no. & Type of organism & Log counts $/ \mathrm{ml} 10$ \\
\hline 1. & $\begin{array}{l}\text { Klebsiella } \\
\text { Pseudomonas } \\
\text { Coliform }\end{array}$ & $\begin{array}{l}6 \cdot 08 \\
5 \cdot 00 \\
4 \cdot 90\end{array}$ \\
\hline 2. & Anaerobic spore bearers & $\begin{array}{l}5.67(\mathrm{BA}) \\
5.00(\mathrm{MAC})\end{array}$ \\
\hline 3. & $\begin{array}{l}\text { Mima Herrellia } \\
\text { Staph. albus } \\
\text { Micrococci }\end{array}$ & $\begin{array}{l}5 \cdot 00 \\
4 \cdot 30 \\
4 \cdot 23\end{array}$ \\
\hline 4. & Klebsiella & $5 \cdot 90$ \\
\hline 5. & $\begin{array}{l}\text { Klebsiella } \\
\text { Strep. viridans } \\
\text { Mima Herrellia }\end{array}$ & $\begin{array}{l}5 \cdot 78 \\
530 \\
5 \cdot 30\end{array}$ \\
\hline 6. & $\begin{array}{l}\text { Entero-cocci } \\
\text { Micrococci }\end{array}$ & $\begin{array}{l}6.00 \\
3.48\end{array}$ \\
\hline 7. & $\begin{array}{l}\text { Aerobic spore bearer } \\
\text { Yeast cells } \\
\text { Anaerobic spore bearing } \\
\text { bacilli }\end{array}$ & $\begin{array}{l}4 \cdot 85 \\
5 \cdot 30 \\
4 \cdot 78\end{array}$ \\
\hline 8. & $\begin{array}{l}\text { Coliform } \\
\text { Mima polymorpha } \\
\text { Anaerobic spore bearer } \\
\text { Staph. albus }\end{array}$ & $\begin{array}{l}5 \cdot 78 \\
5 \cdot 78 \\
4 \cdot 85 \\
5 \cdot 48\end{array}$ \\
\hline
\end{tabular}

BA: blood agar media.

MAC: MacConkey media.
Table 3 Bile salt deconjugation in patients and controls

\begin{tabular}{|c|c|c|c|}
\hline & $\begin{array}{l}\text { Total no. } \\
\text { of cases }\end{array}$ & $\begin{array}{l}\text { Cases } \\
\text { showing } \\
\text { deconjugation } \\
\text { (no.) }\end{array}$ & $(\%)$ \\
\hline $\begin{array}{l}\text { Patients } \\
\text { Controls: }\end{array}$ & 17 & 14 & 82.5 \\
\hline $\begin{array}{l}\text { 1. Irritable bowel syndrome } \\
\text { 2. Giardiasis without malabsorption }\end{array}$ & $\begin{array}{l}8 \\
5\end{array}$ & $\begin{array}{l}\mathbf{0} \\
2\end{array}$ & $\begin{array}{c}0 \\
40 \cdot 0\end{array}$ \\
\hline
\end{tabular}

Table 4 Relation between bacterial overgrowth and bile salt deconjugation in giardiasis patients with steatorrhoea and control subjects

\begin{tabular}{lll}
\hline Bacterial culture of jejunal aspirate & $\begin{array}{l}\text { Total } \\
\text { cases }\end{array}$ & $\begin{array}{l}\text { Cases showing } \\
\text { free bile acids }\end{array}$ \\
\hline Patients with: & & \\
Significant bacterial overgrowth & 8 & 8 \\
'Insignificant' growth & 1 & 1 \\
No bacterial growth & 7 & 5 \\
Controls with: & 2 & 0 \\
Insignificant bacterial growth & 6 & 0 \\
No bacterial growth & 6 & \\
\hline
\end{tabular}

with significant bacterial overgrowth all showed evidence of deconjugation. One patient with a bacterial count of less than the accepted level of significance also had free bile acids in the jejunal aspirate. Of the remaining seven patients with giardiasis with sterile jejunal aspirates, five had evidence of bile salt deconjugation. Two of the five controls who had giardia infection and normal small bowel function showed the presence of free bile acids in the jejunal aspirate even though the duodenal aspirate was sterile. Vegetative form giardia were demonstrated in fresh jejunal aspirates in all the patients examined.

Steatorrhoea was recorded in $27 \%$ of patients with giardiasis in the present study. Reports in the literature are very variable and fat malabsorption has been reported to range from zero (Palumbo et al., 1962; Kotcher et al., 1966) to $50 \%$ (Tewari and Tandon, 1974) of the patients with Giardia lamblia infestation. Either a variable load of infection or certain unidentified host factors may be responsible for the discrepancies in the results of the fat malabsorption in these patients. Undoubtedly giardia infection gives rise to mild to moderate steatorrhoea. The severe degree of fat malabsorption that has been reported in other diffuse small bowel disorders (Bossak et al., 1957) is not observed in this disease. However, if one considers a high prevalence of giardia infection-for example, to the extent of $10 \%$ of the population in developing countries where the people are already receiving inadequate nutrients in their diet-even mild to moderate steatorrhoea is likely to become an important contributory factor 
for protein-energy malnutrition. (Tewari and Tandon, 1974).

The clinical features of patients with and without steatorrhoea were almost the same as those described in the literature. However, patients with steatorrhoea seem to have a more frequent history of passage of large bulky stools associated with weight loss when compared with the group with giardiasis but without steatorrhoea. It is felt that steatorrhoea in the present series of patients was aetiologically related to Giardia lamblia infestation and it seems unlikely that the patients belong to any other category of intestinal disease giving rise to malabsorption. None of the patients had the clinical or biochemical features of dietary protein-energy malnutrition that would raise the possibility of hypoproteinemic enteropathy. Tropical sprue also seems to be an unlikely possibility, as Schilling's test was normal in all the patients and D-xylose excretion was abnormal only in a small number of three patients and none was found to be anaemic. The reversibility studies (Véghelyi, 1939, 1940; Katsampes et al., 1944; Powell, 1956; Tewari and Tandon, 1974) on malabsorption in patients with giardiasis, after eradication of the parasite, support the possibility of a direct aetiological relationship between Giardia lamblia and malabsorption.

The results of the present study suggest that the bacterial overgrowth and bile salt deconjugation are the possible causes of fat malabsorption in patients with giardia infestation. The bile salt deconjugation was recorded in 14 of the 17 patients and bacterial growth with significant colony counts was observed in $48 \%$ of them. None of the eight control cases of irritable bowel syndrome had either bile salt deconjugation or significant bacterial overgrowth in their jejunal aspirates. However, two of the controls with giardia infection and normal small bowel function had bile salt deconjugation without any bacterial overgrowth in the duodenal aspirate.

The mechanism of steatorrhoea in patients with bacterial colonisation of the small intestines has been the subject of study for many years. Normal morphology of the absorptive cell and villi by light (Rubin and Dobbins, 1965) and electron microscope (Tabaqchali et al., 1968) does not support the possibility of direct invasion of mucosa by bacteria. Some investigators (Neale, 1967; Tabaqchali and Booth, 1970) have suggested that protein deficiency may result because of bacterial degradation of dietary protein in the gastrointestinal tract, and hence there is a theoretical possibility of hypoproteinaemic enteropathy in patients with bacterial colonisation of the upper gut. However, normal or only slightly low serum protein values and the absence of clinical features of protein-energy mal- nutrition rule out such a possibility in the present series of patients. Wirts and Goldstein (1963) suggested the possibility that an impaired lipolysis as a result of bacterial inactivation of lipase was responsible for fat malabsorption. Experimental studies (Donaldson, 1965) have failed to confirm this possibility. Dawson and Isselbacher (1960) were the first to suggest that altered bile salt metabolism by bacteria might be responsible for derangement of fat absorption. Normally, colonic bacteria convert the conjugated bile salts to unconjugated forms in the colon. It was suggested that bacterial flora of the upper gut might do the same. The alteration of normal bile salt metabolism by bacterial deconjugation within the lumen could cause steatorrhoea in two ways. Firstly, the unconjugated bile acids might be toxic to intestinal mucosa and, secondly, deconjugation might result in a reduction of the concentration of conjugated bile salts. Tabaqchali and Booth (1966) showed that patients with high bacterial counts in the jejunal fluid with steatorrhoea had large quantities of unconjugated bile acids in lumen of small intestine. Treatment with broad spectrum antibiotics reduced jejunal bacterial counts and the disappearance of free bile acids, associated with improvement in fat absorption.

It is now generally agreed that, in patients with small bowel bacterial overgrowth, the flora come to resemble faecal flora. An association between the presence of bacteroides and bile salt deconjugation has been stressed in the literature (Tabaqchali, 1974), but none of the patients in the present series had these bacteria in the small bowel. Techniques used for anaerobic culture in this study might have missed the bacteroides or this might be a characteristic finding in our patients that was probably related to the internal milieu of the small bowel. The association of bile salt deconjugation with aerobic as well as anaerobic bacteria in the absence of demonstrable bacteroides in the small bowel has been reported by a few earlier investigators (Goldstein et al., 1969). Hydrolysis of conjugated bile salts has been produced in vitro by Streptococcus lactis and Lactobacillus buchneri (Shimada et al., 1969) as well as by E. coli (Norman and Shorb, 1962; Portman et al., 1962; Midtvedt and Norman, 1967; Dickinson et al., 1971). It is thus possible that the aerobic coliforms or the streptococal organisms isolated in our patients may explain the pathogenesis of bile salt deconjugation even in the absence of bacteroides or other anaerobic micro-organisms.

Bacterial colonisation seems to be primarily responsible for bile salt deconjugation in the patients with giardia infection. However, it is interesting to note that seven patients with giardiasis in the present series (five study and two control group) had free bile 
acids in the bacteriologically sterile jejunal aspirates. It is likely that Giardia lamblia itself is capable of deconjugating bile salts. Further in vitro studies to confirm the direct role of Giardia lamblia in bile salt deconjugation are warranted in the light of the present observations.

Two patients with giardia infection with bile salt deconjugation did not have steatorrhoea. Quantitative aspects of bile salt deconjugation need to be studied to explain this finding.

\section{References}

Amini, F. (1963). Giardiasis and steatorrhoea. Journal of Tropical Medicine and Hygiene, 66, 190-192.

Antia, F. P., Desai, H. G., Jeejeebhoy, K. N., Kane, M. P., and Borkar, A. V. (1966). Giardiasis in adults. Incidence, symptomatology and absorption studies. Indian Journal of Medical Science, 20, 471-477.

Bossak, E. T., Wang, C. I., and Aldersberg, D. (1957). Clinical aspects of the malabsorption syndrome. Mount Sinai Hospital Journal, 24, 286-303.

Brandborg, L. L., Tankersley, C. B., Gottlieb, S., Barancik, M., and Sartor, V. E. (1967). Histological demonstration of mucosal invasion by Giardia lamblia in man. Gastroenterology, 52, 143-150.

Cortner, J. A. (1961). Giardiasis in childhood. Quarterly Review of Paediatrics, 16, 218-220.

Cruickshank, R. (1965) Medical Microbiology, 11th edn. Livingstone: Edinburgh.

Dawson, A. M., and Isselbacher, K. J. (1960). Studies on lipid metabolism in the small intestine with observations on the role of bile salts. Journal of Clinical Investigation, $39,730-740$.

Dickinson, A. B., Gustafsson, B. E., and Norman, A. (1971). Determination of bile acid conversion potencies of intestinal bacteria by screening in vitro. and subsequent development in germfree rats. Acta Pathologica et Microbiologica Scandinavica, sect. B. 79, 691 .

Donaldson, R. M. Jr (1965). Studies on the pathogenesis of steatorrhoea in the blind loop syndrome. Journal of Clinical Investigation, 44, 1815-1825.

Fahey, J. L., and McKelvey, E. M. (1965). Quantitative determination of serum immunoglobulins in antibodyagar plates. Journal of Immunology, 94, 84-90.

Goldstein, F., Wirts, C. W., Salen, G., and Mandle, R. J. (1969). Diverticulosis of the small intestine: clinical, bacteriologic and metabolic observations in a group of seven patients. American Journal of Digestive Disorders, 14, 170-181.

Gorbach, S. L., and Tabaqchali, S. (1969). Bacteria, bile and the small bowel. Gut, 10, 963-972.

Hoskins, L. C., Winawer, S. J., Broitman, S. A., Gottlieb, L. S., and Zamcheck, N. (1967). Clinical giardiasis and intestinal malabsorption. Gastroenterology, 53, 265-279.

Kapadia, C. R., Radhakrishnan, A. N., Mathan, V. I., and Baker, S. J. (1971). Studies on bile salt deconjugation in patients with tropical sprue. Scandinavian Journal of Gastroenterology, 6, 29-31.

Katsampes, C. P., McCoord, A. B., and Phillips, W. A. (1944). Vitamin A absorption test in cases of giardiasis. American Journal of Diseases of Children, 67, 189-193.

King, E. J. (1964). Micro-Analysis in Medical Biochemistry, 4th edn, p. 207. Edited by I. D. P. Wootton. Churchill: London.

Kotcher, E., Miranda, M., Esquivel, R., Pena-Chavarria, A.,
Donohugh, D. L., Baldizon, C., Acosta, A., and Apuy, J. L. (1966). Intestinal malabsorption and helminthic and protozoan infections of the small intestine. Gastroenterology, 50, 366-371.

Blair, J. E., Lennette, E. H., and Truant, J. P. (1970). Manual of Clinical Microbiology. American Society for Microbiology: Bethesda, Maryland.

Manson-Bahr, P. (1943). The Dysenteric Disorders, p. 258. Cassell: London.

Midtvedt, T., and Norman, A. (1967). Bile acid transformations by microbial strains belonging to genera found in intestinal contents. Acta Pathologica et Microbiologica Scandinavica, 71, 629-638.

Nair, K. P. B. (1970). Giardiasis in children: study of its symptomatology. Indian Practititioner, 23, 145-154.

Neale, G. (1967). Protein deficiency in temperate zones. Proceedings of the Royal Society of Medicine, 60, 1069-1071.

Norman, A., and Shorb, M. S. (1962). In vitro formation of deoxycholic and lithocholic acid by human intestinal micro-organisms. Proceedings of the Society for Experimental Biology and Medicine, 110, 552-555.

Palumbo, P. J., Scudamore, H. H., and Thompson, J. H. (1962). Relationship of infestation with giardia lamblia to intestinal malabsorption syndromes. Proceedings of the Mayo Clinic, 37, 589-598.

Portman, O. W., Shah, S., Antonis, A., and Jorgensen, B. (1962). Alteration of bile salts by bacteria. Proceedings of the Society for Experimental Biology and Medicine, 109, 959-965.

Powell, E. D. (1956). Giardiasis. Irish Journal of Medical Science, 34, 510-517.

Rubin, C. E., and Dobbins, W. O. (1965). Peroral biopsy of the small intestine. A review of its diagnostic usefulness. Gastroenterology, 49, 676-697.

Santini, R. Jr, Sheehy, T. W., and Martinez-de Jesus, J. (1961). The xylose tolerance test with a $5 \mathrm{~g}$ dose. Gastroenterology, 40, 772-774.

Schilling, R. F. (1953). Intrinsic factor studies II. The effect of gastric juice on the urinary excretion of radioactivity after the oral administration of radio-active vitamin $B_{12}$. Journal of Laboratory and Clinical Medicine, 42, 860-866.

Shimada, K., Bricknell, K. S., and Finegold, S. M. (1969). Deconjugation of bile acids by intestinal bacteria: review of literature and additional studies. Journal of Infectious Diseases, 119, 273-281.

Stokes, E. Joan (1968). Clinical Bacteriology, 3rd edn. Arnold: London.

Tabaqchali, S., Hatzioannou, J., and Booth, C. C. (1968). Bile salt deconjugation and steatorrhoea in patients with the stagnant-loop syndrome. Lancet, 2, 12-16.

Tabaqchali, S., and Booth, C. C. (1970). Bacteria and the small intestine. Modern Trends in Gastroenterology, p. 143. Edited by W. I. Card and B. Creamer. Butterworths: London.

Tabaqchali, S., and Booth, C. C. (1966). Jejunal bacteriology and bile salt metabilism in patients with intestinal malabsorption. Lancet, 2, 12-15.

Tabaqchali, S. (1974). Ecology and metabolic activity of non-sporing anaerobes. In Infection with Non-Sporing Anaerobic Bacteria, p. 59. Edited by M. Phillips and I. Sussman. Churchill Livingstone: Edinburgh.

Tandon, B. N., Puri, B. K., Gandhi, P. C., and Tewari, S. G. (1974). Mucosal surface injury of jejunal mucosa in patients with giardiasis-an electron microscopic study. Indian Journal of Medical Research, 62, 1838-1842.

Tewari, S. G., and Tandon, B. N. (1974). Functional and histological changes of small bowel in patients with giardia lamblia infestation. Indian Journal of Medical Research, 62, 689-695.

Véghelyi, P. V. (1939). Absorption studies in children with 
giardia lamblia infection. Archives of Disease in Childhood, 14, 155-158.

Véghelyi, P. V. (1940). Giardiasis. American Journal of Diseases in Children, 59, 793-804.

Wirts, C. W., and Goldstein, F. (1963). Studies of the mechanism of postgastrectomy steatorrhea. Annals of Internal Medicine, 58, 25-36.

Yardley, J. H., Takano, J., and Hendrix, T. R. (1964).
Epithelial and other mucosal lesions of the jejunum in giardiasis. Jejunal biopsy studies. Bulletin of the Johns Hopkins Hospital, 115, 389-406.

Zamcheck, N., Hoskins, L. C., Winawer, S. J., Broitman, S. A., and Gottlieb, L. S. (1963). Histology and ultrastructure of the parasite and the intestinal mucosa in human giardiasis. Effects of atebrine therapy. Gastroenterology, 44, 860 . 